\title{
PENGARUH ETIKA PROFESI DAN SKEPTISISME PROFESIONAL AUDITOR TERHADAP KETEPATAN PEMBERIAN OPINI OLEH AKUNTAN PUBLIK PADA EKSTERNAL AUDITOR DI KANTOR AKUNTAN PUBLIK WILAYAH TANGERANG SELATAN
}

\author{
1*Dian Purwanti, ${ }^{2}$ Resa Nurmala \\ Universitas Muhammadiyah Sukabumi, Jawa Barat, Indonesia \\ 1*dianpurwanti042@ummi.ac.id, ${ }^{2}$ resanurmala@ummi.ac.id
}

\begin{abstract}
Abstrak
Penelitian ini bertujuan untuk mengetahui pengaruh etika profesi dan skeptisisme profesional auditor terhadap ketepatan pemberian opini oleh akuntan publik pada Eksternal Auditor di Kantor Akuntan Publik Wilayah Tangerang Selatan.Metode yang digunakan adalah explanatory research dengan teknik anali sis menggunakan analisis statistik dengan pengujian regresi, korelasi, determinasi dan uji hipotesis. Hasil penelitian ini etika profesi berpengaruh signifikan terhadap ketepatan pemberian opini oleh akuntan publik sebesar 48,0\%, uji hipotesis diperoleh $t$ hitung $>t$ tabel atau $(7,321>1,989)$. Skeptisisme profesional auditor berpengaruh signifikan terhadap ketepatan pemberian opini oleh akuntan publik sebesar $44,2 \%$, uji hipotesis diperoleh $t$ hitung $>t$ tabel atau $(6,781>1,989)$. Etika profesi dan skeptisisme profesional auditor secara simultan berpengaruh signifikan terhadap ketepatan pemberian opini oleh akuntan publik dengan persamaan regresi $\mathrm{Y}=7,494+0,418 \mathrm{X} 1+$ 0,441X2 dan kontribusi pengaruh sebesar 62,4\%, uji hipotesis diperoleh $\mathrm{F}$ hitung $>\mathrm{F}$ tabel atau $(47,347>2,770)$.
\end{abstract}

Kata Kunci: Etika Profesi, Skeptisisme Profesional Auditor, Ketepatan Pemberian Opini.

\begin{abstract}
This study aims to determine the effect of professional ethics and professional skepticism of auditors on the accuracy of giving opinions by public accountants to external auditors at the South Tangerang Regional Public Accountant Office. The method used is explanatory research with analytical techniques using statistical analysis with regression, correlation, determination testing. and hypothesis testing. The results of this study that professional ethics have a significant effect on the accuracy of giving opinions by public accountants by 48.0\%, hypothesis testing is obtained $t$ count $>t$ table or $(7,321>1,989)$. Auditor professional skepticism has a significant effect on the accuracy of giving opinions by public accountants by $44.2 \%$, hypothesis testing is obtained t count $>t$ table or $(6.781>1.989)$. Professional ethics and professional skepticism of auditors simultaneously have a significant effect on the accuracy of giving opinions by public accountants with the regression equation $Y=7,494+0,418 X 1+0,441 X 2$ and the contribution of influence is $62.4 \%$, hypothesis testing is obtained F count $>$ F table or (47.347 > 2,770).
\end{abstract}

Keywords: Professional Ethics, Auditor Professional Skepticism, Accuracy in Giving Opinions.

\section{PENDAHULUAN}

Setiap perusahaan membutuhkan laporan keuangan, dimana laporan keuangan ini menggambarkan bagaimana keadaan perusahaan yang sebenarnya, sehingga diharapkan laporan keuangan ini dapat di yakini kebenarannya baik bagi pengguna internal maupun ekstemal perusahaan, untuk dapat meyakini kebenaran laporan keuangan tersebut perusahaan membutuhkan pihak independen yakni Auditor ekstemal yang bekerja di Kantor Akuntan Publik (KAP) yang akan melaksanakan proses Auditing dan memberikan opini terhadap laporan keuangan tersebut.

Auditing adalah suatu pemeriksaan yang dilakukan secara kritis dan sistematis, oleh pihak yang independen, terhadap laporan keuangan yang telah disusun oleh manajemen, beserta catatan-catatan pembukuan dan bukti bukti pendukungnya, dengan tujuan dapat memberikan pendapat mengenai kewajaran laporan keuangan tersebut (Sukrisno Agoes, 2012:4).

Tujuan akhir dari proses auditing adalah menghasilkan laporan audit, laporan audit inilah yang akan digunakan oleh 
auditor untuk menyampaikan pemyataan atau pendapatnya pada pemakai laporan keuangan (Gusti \& Ali, 2008:2). Dari tujuan tersebut dapat disimpulkan bahwa Opini Akuntan Publik (Auditor) sangatlah penting, karena merupakan hasil akhir dari proses Auditing.

Dalam penelitian terdahulu bahwa Skeptisisme Profesional Auditor berpengaruh positif terhadap Ketepatan Pemberian Opini Akuntan Publik (Ida suraida, 2005), Opini auditor merupakan pendapat yang diberikan oleh auditor tentang kewajaran penyajian lapoaran keuangan perusahaan tempat auditor melakukan audit (Gusti \& Ali, 2008:6). Dalam menentukan Opini harus disertai dengan bukti-bukti yang kompeten. Untuk memperoleh bukti• bukti tersebut, seorang auditor harus senantiasa menggunakan skeptisisme profesionalnya yaitu sikap yang mencakup pikiran yang selalu mempertanyakan dan melakukan evaluasi secara kritis terhadap bukti audit (SPAP 2001; SA, seksi 230) dalam (Ida suraida, 2005:187). Skeptisisme Profesional Auditor dapat dipengaruhi oleh beberapa faktor. Faktor-faktor tersebut antara lain keahlian, pengetahuan, kecakapan, pengalaman, situasi audit yang dihadapi dan etika (Gusti \& Ali, 2008:3).

\section{Faktor-faktor lain yang}

mempengaruhi auditor dalam pengambilan keputusan untuk memberikan Opini audit adalah etika profesi auditor, komitmen profesional dan pengalaman kerja audit (Dewi \& Dharma, 2013). Dalam melaksanakan tugasnya seorang auditor harus berpedoman pada kode etik yang telah di tetapkan dan bekerja sesuai dengan prinsip etika profesi yang telah diatur dalam kode etik agar tujuan profesi akuntansi tercapai. Menurut Sukrisno Agoes (2012:42), "Kode Etik Profesi Akuntan Publik adalah pedoman bagi para anggota Institut Akuntan Publik Indonesia (IAPI) untuk bertugas secara bertanggung jawab dan objektif Akan tetapi dalam kenyataannya bukan sedikit KAP yang melanggar kode etik yang menyebabkan kepercayaan masyarakat hilang terhadap Akuntan Publik.

Ada beberapa kasus yang Berkaitan dengan kesalahan dalam memberikan Opini serta penyimpangan Etika profesi baik yang dilakukan oleh KAP Bigfour maupun selain Bigfour. Kasus dimaksud salah satunya yaitu kasus Olympus yang terkait gugatan yang diajukan 6 bank besar di Jepang terhadap penipuan yang dilakukan Olympus. Bank-bank tersebut menggugat atas nama kliennya yang tertipu karena selama 11 tahun laporan keuangan Olympus selalu mencantumkan laba yang besar, sebelum akhirnya ketahuan keropos pada tahun 2011. Korporasi besar, pastilah diaudit laporan keuangannya oleh Kantor Akuntan Publik (KAP) yang punya reputasi internasional. Ada 4 KAP yang menguasai dunia, termasuk Jepang dan juga Indonesia, yakni Ernst \& Young, Price Waterhouse Cooper, Deloitte, dan KPMG. Kemuadian, korporasi besar juga di rating oleh rating agency terkemuka. Penguasa rating agency dunia saat ini ada 3 perusahaan, yakni Moodys, S\&P, dan Fitch.Olympus tentunya di audit dan di-rating secara periodik (kompasiana.com).

Berdasarkan latar belakang tersebut di atas, maka penulis tertarik melakukan penelitian dengan judul Pengaruh Etika Profesi dan Skeptisisme Profesional Auditor terhadap Ketepatan Pemberian Opini Akuntan Publik.

\section{TINJAUAN PUSTAKA \\ 1. Etika profesi}

Etika merupakan peraturanperaturang yang dirancang untuk mempertahankan suatu profesi pada tingk:at yang bermartabat, mengarah anggota profesi dalam hubungannya dengan yang lain, dan memastikan kepada publik bahwa profesi akan mempertahankan tingkat kinerja yang tinggi (Danang Sunyoto, 2014:39).

\section{Skeptisisme profesional auditor}

Skeptisisme profesionalnya yaitu sikap yang mencakup pikiran yang selalu mempertanyakan dan melakukan evaluasi secara kritis terhadap bukti audit (SPAP 2001; SA, seksi 230) dalam (Ida suraida, 2005:187).

\section{Ketepatan pemberian opini oleh akuntan publik \\ Opini auditor atas laporan}


keuangan menyatakan apakah laporan keuangan disusun dalam semua hal yang material sesuai dengan kerangka pelaporan keuangan yang berlaku (SPAP 2013: SA seksi 200). Menurut Standar Profesional Akuntan Publik Per 31 Maret 2011 (PSA 29 SA seksi 508) dalam Sukrisno Agoes (2012:75) Opini / pendapat akuntan publik terdiri dari lima jenis , yaitu :1) Pendapat wajar tanpa pengecualian, 2) Pendapat wajar tanpa pengecualian dengan bahasa penjelasan yang ditambahkan dalam laporan audit bentuk baku, 3) Pendapat wajar dengan pengecualian, 4) Pendapat tidak wajar

\section{METODE}

Populasi dalam penelitian ini berjumlah 60 responden Eskternal Auditor di

Tabel 1. Hasil Analisis Descriptive Statistics

\section{Descriptive Statistics}

N Minimum Maximum Mean Std. Deviation

\begin{tabular}{|l|l|l|l|l|l|}
\hline Etika (X1) & 60 & 31 & 48 & 37.35 & 4.230 \\
\hline Skeptis (X2) & 60 & 28 & 45 & 37.22 & 3.827 \\
\hline Opini (Y) & 60 & 31 & 47 & 38.38 & 3.636 \\
\hline Valid N (listwise) & 60 & & & & \\
\hline
\end{tabular}

Etika profesi diperoleh varians minimum sebesar 31 dan varians maximum 48 dengan mean score sebesar 3,73 dengan standar deviasi 4,230.

Skeptisisme profesional auditor diperoleh varians minimum sebesar 28 dan varians maximum 45 dengan mean score sebesar 3,72 dengan standar deviasi 3,827.

Ketepatan pemberian opini oleh akuntan publik diperoleh varians minimum sebesar 31 dan varians maximum 47 dengan mean score sebesar 3,83 dengan standar deviasi 3,636.
Kantor Akuntan Publik Wilayah Tangerang Selatan. Sampel dalam penelitian ini berjumlah 60 responden. Jenis penelitian yang dipakai adalah asosiatif, dimana tujuannya adalah untuk mengetahui pengaruh antara variabel bebas terhadap variabel terikat baik parsial maupun simultan. Dalam menganalisis data digunakan uji instrumen, uji asumsi klasik, regresi, koefisien determinasi dan uji hipotesis.

\section{HASIL DAN PEMBAHASAN}

\section{Analisis Deskriptif}

Pada pengujian ini digunakan untuk mengetahui skor minimum dan maksimum, mean score dan standar deviasi dari masing-masing variabel. Adapun hasilnya sebagai berikut:

\section{Analisis Kuantitatif}

Pada analisis ini dimaksudkan untuk mengetahui pengaruh variabel independen terhadap variabel dependen baik secara parsial maupun secara simultan. Adapun hasil pengujian sebagai berikut:

\section{a. Analisis Regresi Linier Berganda}

Uji regresi ini dimaksudkan untuk mengetahui perubahan variabel dependen jika variabel independen mengalami perubahan. Adapun hasil pengujiannya sebagai berikut:

Tabel 2. Hasil Pengujian Regresi Linier Berganda

\section{Coefficients ${ }^{\mathrm{a}}$}

Unstandardized Coefficients Standardized Coefficients

\begin{tabular}{l|r|r|r|r|r} 
Model & B & Std. Error & Beta & $t$ & Sig. \\
\hline 1 (Constant) & 7.494 & 3.209 & & 2.335 & .023 \\
\hline Etika (X1) & .418 & .080 & .486 & 5.255 & .000 \\
\hline Skeptis (X2) & .411 & .088 & .432 & 4.673 & .000 \\
\hline
\end{tabular}

a. Dependent Variable: Opini (Y)

Berdasarkan hasil pengujian pada tabel di atas, diperoleh persamaan regresi $Y=7,494+0,418 X 1+0,441 X 2$.
Dari persamaan tersebut dijelaskan sebagai berikut:

1) Konstanta sebesar 7,494 diartikan 
jika etika profesi dan skeptisisme profesional auditor tidak ada, maka telah terdapat nilai ketepatan pemberian opini oleh akuntan publik sebesar 7,494 point.

2) Koefisien regresi etika profesi sebesar 0,418, angka ini positif artinya setiap ada peningkatan etika profesi sebesar 0,418 maka ketepatan pemberian opini oleh akuntan publik juga akan mengalami peningkatan sebesar 0,418 point.

3) Koefisien regresi skeptisisme profesional auditor sebesar 0,441, angka ini positif artinya setiap ada

Tabel 3. Hasil Pengujian Koefisien Korelasi Etika profesi Terhadap Ketepatan pemberian opini oleh akuntan publik.

Correlations $^{\mathbf{b}}$

\begin{tabular}{llr|r} 
& & Etika (X1) & Opini (Y) \\
\hline \multirow{2}{*}{ Etika (X1) } & Pearson Correlation & 1 & $.693^{* *}$ \\
\cline { 2 - 4 } & Sig. (2-tailed) & & .000 \\
\hline \multirow{2}{*}{ Opini (Y) } & Pearson Correlation & $.693^{* *}$ & 1 \\
\cline { 2 - 4 } & Sig. (2-tailed) & .000 & \\
\hline \multirow{2}{*}{$* *$. Correlation is significant at the 0.01 level (2-tailed). }
\end{tabular}

b. Listwise $\mathrm{N}=60$

Berdasarkan hasil pengujian diperoleh nilai korelasi sebesar 0,693 artinya etika profesi memiliki

hubungan yang kuat terhadap ketepatan pemberian opini oleh akuntan publik.

Tabel 4. Hasil Pengujian Koefisien Korelasi Skeptisisme profesional auditor Terhadap Ketepatan pemberian opini oleh akuntan publik.

\section{Correlations ${ }^{\mathrm{b}}$}

\begin{tabular}{llr|r} 
& \multicolumn{2}{r}{ Skeptis (X2) } & Opini (Y) \\
\hline Skeptis (X2) & Pearson Correlation & 1 & $.665^{* *}$ \\
\cline { 2 - 4 } & Sig. (2-tailed) & & .000 \\
\hline \multirow{2}{*}{ Opini (Y) } & Pearson Correlation & $.665^{* *}$ & 1 \\
\cline { 2 - 4 } & Sig. (2-tailed) & .000 & \\
\hline
\end{tabular}

**. Correlation is significant at the 0.01 level (2-tailed).

b. Listwise $\mathrm{N}=60$

Berdasarkan hasil pengujian diperoleh nilai korelasi sebesar 0,665 artinya skeptisisme profesional auditor

memiliki hubungan yang kuat terhadap ketepatan pemberian opini oleh akuntan publik.

Tabel 5. Hasil Pengujian Koefisien Korelasi Etika profesi dan Skeptisisme profesional auditor secara simultan Terhadap Ketepatan pemberian opini oleh akuntan publik.

\section{Model Summary}

\begin{tabular}{ll|l|l|l} 
Model & R & R Square & Adjusted R Square & Std. Error of the Estimate \\
\hline 1
\end{tabular}

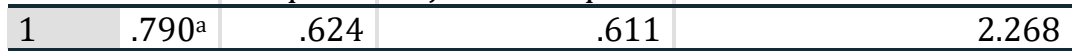

a. Predictors: (Constant), Skeptis (X2), Etika (X1)

Berdasarkan hasil pengujian diperoleh nilai korelasi sebesar 0,790 artinya etika profesi dan skeptisisme profesional auditor secara simultan memiliki hubungan yang kuat terhadap ketepatan pemberian opini oleh akuntan publik. 


\section{c. Analisis Koefisien Determinasi}

Analisis koefisien determinasi dimaksudkan untuk mengetahui besarnya persentase pengaruh dari variabel independen terhadap variabel dependen baik secara parsial maupun simultan. Adapun hasil pengujian sebagai berikut:

Tabel 6. Hasil Pengujian Koefisien Determinasi Etika profesi Terhadap Ketepatan pemberian opini oleh akuntan publik.

\section{Model Summary}

\begin{tabular}{lr|r|r|r} 
Model & R & R Square & Adjusted R Square & Std. Error of the Estimate \\
\hline 1 & $.693^{\mathrm{a}}$ & .480 & .471 & 2.644 \\
\hline
\end{tabular}

a. Predictors: (Constant), Etika (X1)

Berdasarkan hasil pengujian diperoleh nilai determinasi sebesar 0,480 artinya etika profesi memiliki Tabel 7. Hasil Pengujian Koefisien Determinasi Skeptisisme profesional auditor Terhadap Ketepatan pemberian opini oleh akuntan publik.

\section{Model Summary}

\begin{tabular}{lr|r|r|r} 
Model & R & R Square & Adjusted R Square & Std. Error of the Estimate \\
\hline 1 & $.665^{\mathrm{a}}$ & .442 & .433 & 2.739 \\
\hline a. Predictors: (Constant), Skeptis (X2)
\end{tabular}

Berdasarkan hasil pengujian diperoleh nilai determinasi sebesar 0,442 artinya skeptisisme profesional

auditor memiliki kontribusi pengaruh sebesar $44,2 \%$ terhadap ketepatan pemberian opini oleh akuntan publik.

Tabel 8. Hasil Pengujian Koefisien Determinasi Etika profesi dan Skeptisisme profesional auditor Terhadap Ketepatan pemberian opini oleh akuntan publik.

\section{Model Summary}

\begin{tabular}{lr|r|r|r} 
Model & R & R Square & Adjusted R Square & Std. Error of the Estimate \\
\hline 1 & $.790^{\mathrm{a}}$ & .624 & .611 & 2.268 \\
\hline a. Predictors: (Constant), Skeptis (X2), Etika (X1)
\end{tabular}

Berdasarkan hasil pengujian diperoleh nilai determinasi sebesar 0,624 artinya etika profesi dan skeptisisme profesional auditor secara simultan memiliki kontribusi pengaruh sebesar $62,4 \%$ terhadap ketepatan pemberian opini oleh akuntan publik, sedangkan sisanya sebesar $37,6 \%$ dipengaruhi faktor lain.

\section{d. Uji Hipotesis}

Uji hipotesis Parsial (Uji t)

Tabel 9. Hasil Uji Hipotesis Etika profesi Terhadap Ketepatan pemberian opini oleh akuntan publik.

\section{Coefficients}

Unstandardized Coefficients Standardized Coefficients

\begin{tabular}{lr|r|rrr|r}
\multicolumn{1}{l}{ Model } & \multicolumn{1}{c}{ B } & Std. Error & Beta & \multicolumn{1}{c}{ t } & Sig. \\
\hline 1 (Constant) & 16.130 & 3.059 & & & 5.274 & .000 \\
\hline Etika (X1) & .596 & .081 & .693 & 7.321 & .000 \\
\hline
\end{tabular}

a. Dependent Variable: Opini (Y)

Berdasarkan hasil pengujian pada tabel di atas, diperoleh nilai $\mathrm{t}$ hitung $>\mathrm{t}$ tabel atau $(7,321>1,989)$,
Pengujian hipotesis dengan uji $t$ digunakan untuk mengetahui hipotesis parsial mana yang diterima.

Hipotesis pertama: Terdapat pengaruh yang signifikan etika profesi terhadap ketepatan pemberian opini oleh akuntan publik.

Hipotesis kedua: Terdapat pengaruh yang signifikan antara skeptisisme profesional auditor terhadap ketepatan pemberian opini oleh akuntan publik. 
profesi terhadap ketepatan pemberian

opini oleh akuntan publik diterima.

Tabel 10. Hasil Uji Hipotesis Skeptisisme profesional auditor Terhadap Ketepatan pemberian opini oleh akuntan publik.

\section{Coefficients $^{a}$}

\begin{tabular}{|c|c|c|c|c|c|}
\hline \multirow[b]{2}{*}{ Model } & \multicolumn{2}{|c|}{ Unstandardized Coefficients } & \multirow{2}{*}{$\begin{array}{c}\text { Standardized Coefficients } \\
\text { Beta }\end{array}$} & & \multirow[b]{2}{*}{ Sig. } \\
\hline & $\mathrm{B}$ & Std. Error & & & \\
\hline 1 (Constant) & 14.869 & 3.486 & & 4.265 & .000 \\
\hline Skeptis (X2) & .632 & .093 & .665 & 6.781 & .000 \\
\hline
\end{tabular}

a. Dependent Variable: Opini (Y)

Berdasarkan hasil pengujian pada tabel di atas, diperoleh nilai $\mathrm{t}$ hitung $>\mathrm{t}$ tabel atau $(6,781>1,989)$, dengan demikian hipotesis kedua yang diajukan bahwa terdapat pengaruh yang signifikan atara skeptisisme profesional auditor terhadap ketepatan pemberian opini oleh akuntan publik diterima.

Tabel 11. Hasil Uji Hipotesis Etika profesi dan Skeptisisme profesional auditor Terhadap Ketepatan pemberian opini oleh akuntan publik.

\section{ANOVA $^{\mathrm{a}}$}

\begin{tabular}{l|r|r|r|c|c} 
Model & Sum of Squares & df & Mean Square & F & Sig. \\
\hline 1 Regression & 487.024 & 2 & 243.512 & 47.347 & $.000^{\mathrm{b}}$ \\
\hline Residual & 293.159 & 57 & 5.143 & & \\
\hline Total & 780.183 & 59 & & & \\
\hline
\end{tabular}

a. Dependent Variable: Opini (Y)

b. Predictors: (Constant), Skeptis (X2), Etika (X1)

Berdasarkan hasil pengujian pada tabel di atas, diperoleh nilai $\mathrm{F}$ hitung > F tabel atau $(47,347>2,770)$, dengan demikian hipotesis ketiga yang diajukan bahwa terdapat pengaruh yang signifikan atara etika profesi dan skeptisisme profesional auditor terhadap ketepatan pemberian opini oleh akuntan publik diterima.

\section{Pembahasan Hasil Penelitian}

\section{Pengaruh Etika profesi Terhadap Ketepatan pemberian opini oleh akuntan publik}

Etika profesi berpengaruh signifikan terhadap ketepatan pemberian opini oleh akuntan publik dengan korelasi sebesar 0,693 atau memiliki hubungan yang kuat dengan kontribusi pengaruh sebesar $48,0 \%$. Pengujian hipotesis diperoleh nilai $\mathrm{t}$ hitung $>\mathrm{t}$ tabel atau $(7,321>1,989)$. Dengan demikian hipotesis pertama yang diajukan bahwa terdapat berpengaruh signifikan antara etika profesi terhadap ketepatan pemberian opini oleh akuntan publik diterima.

2. Pengaruh Skeptisisme profesional auditor Terhadap Ketepatan pemberian opini oleh akuntan publik

Skeptisisme profesional auditor berpengaruh signifikan terhadap ketepatan pemberian opini oleh akuntan publik dengan korelasi sebesar 0,665 atau memiliki hubungan yang kuat dengan kontribusi pengaruh sebesar 44,2\%. Pengujian hipotesis diperoleh nilai $t$ hitung $>\mathrm{t}$ tabel atau $(6,781>1,989)$. Dengan demikian hipotesis kedua yang diajukan bahwa terdapat berpengaruh signifikan antara skeptisisme profesional auditor terhadap ketepatan pemberian opini oleh akuntan publik diterima.

3. Pengaruh Etika profesi dan Skeptisisme profesional auditor Terhadap Ketepatan pemberian opini oleh akuntan publik

Etika profesi dan skeptisisme profesional auditor berpengaruh 
signifikan terhadap ketepatan pemberian opini oleh akuntan publik dengan diperoleh persamaan regresi $\mathrm{Y}=7,494+$ $0,418 \mathrm{X} 1+0,441 \mathrm{X} 2$, nilai korelasi sebesar 0,790 atau memiliki hubungan yang kuat dengan kontribusi pengaruh sebesar $62,4 \%$ sedangkan sisanya sebesar $37,6 \%$ dipengaruhi faktor lain. Pengujian hipotesis diperoleh nilai $\mathrm{F}$ hitung $>\mathrm{F}$ tabel atau $(47,347>2,770)$. Dengan demikian hipotesis ketiga yang diajukan bahwa terdapat berpengaruh signifikan antara etika profesi dan skeptisisme profesional auditor terhadap ketepatan pemberian opini oleh akuntan publik diterima.

\section{PENUTUP}

\section{Simpulan}

1. Etika profesi berpengaruh signifikan terhadap ketepatan pemberian opini oleh akuntan publik dengan kontribusi pengaruh sebesar 48,0\%. Uji hipotesis diperoleh nilai $\mathrm{t}$ hitung $>\mathrm{t}$ tabel atau $(7,321>1,989)$.

2. Skeptisisme profesional auditor berpengaruh signifikan terhadap ketepatan pemberian opini oleh akuntan publik dengan kontribusi pengaruh sebesar 44,2\%. Uji hipotesis diperoleh nilai thitung $>\mathrm{t}$ tabel atau $(6,781>1,989)$.

3. Etika profesi dan skeptisisme profesional auditor berpengaruh signifikan terhadap ketepatan pemberian opini oleh akuntan publik dengan kontribusi pengaruh sebesar $62,4 \%$ sedangkan sisanya sebesar $37,6 \%$ dipengaruhi faktor lain. Uji hipotesis diperoleh nilai $\mathrm{F}$ hitung $>\mathrm{F}$ tabel atau $(47,347>2,770)$.

\section{Saran}

Berdasarkan pembahasan dan kesimpulan penelitian ini serta hasil data yang telah diteliti, maka peneliti memberikan saran-saran sebagai berikut:

1. Jika ingin melakukan penelitian di KAP, usahakan pada bulan mei hingga bulan November, karena di bulan-bulan tersebut, KAP tidak terlalu sibuk.

2. Usahakan survei terlebih dahulu untuk memastikan KAP yang mau dijadikan objek penelitian serta pastikan jumlah sampel yang akan di teliti.
3. Tanyakan pada KAP yang bersangkutan bersedia atau tidaknya memberikan surat pernyataan tentang riset, dan

4. Untuk peneliti selanjutnya diharapkan dapat menemukan variabel baru yang mempengaruhi Ketepatan Pemberian Opini oleh Akuntan Publik dan juga variabel tersebut berbeda dari variabel penelitan sebelumnya

\section{DAFTAR PUSTAKA}

Agoes, Sukrisno dan Jan Hoesada. "Bunga Rampai auditing." Edisi 2, Salemba Empat, Jakarta 2012.

Agoes, Sukrisno. "Auditing (Petunjuk Praktis Pemeriksaan Akuntan olehAkuntan Publik)." Buku 1, edisi keempat. Salemba Empat, Jakarta, 2012.

Dewi Rharasati, Istri dan Dharma Suputra. "Faktor-faktor yang mempengaruhi Auditor dalam Pengambilan Keputusan untuk Memberikan Opini Audit". Ejurnal Akuntansi Universitas Udayana 3.3 (2013) : 147-162.

Elder, Randal J, Mark S. Beasley Dkk. "Jasa Audit dan Assurance." Buku, Salemba Empat, Jakarta, 2011.

Ghozali, imam. "Aplikasi Analisis Multivariate dengan program IBM SPSS 21". Cetakan VII. Badan Penerbit Universitas Diponegoro, Semarang, 2013

Gusti, Maghfirah dan Syahril Ali. "Hubungan Skeptisisme Profesional Auditor dan Situasi Audit, Etika, Pengalaman serta Keahlian Audit dengan Ketepatan Pemberian Opini Auditor oleh Akuntan". Simposium Nasional Akuntansi (SNA) ke XI, Pontianak, 2008. Institut Akuntan Publik Indonesia, "Tujuan Keseluruhan Auditor Independen dan Pelaksanaan Audit berdasarkan Standar Audit." Seksi 200, Salemba Empat, Jakarta, 2013.

Haque, M. G., Nurjaya, N., Affandi, A., Erlangga, H., \& Sunarsi, D. (2021). Micro Financial Sharia Non-bank Strategic Analysis: a Study at BMT Beringharjo, Yogyakarta. Budapest International Research and Critics Institute (BIRCI-Journal): Humanities and Social Sciences, 4(2), 1677-1686.

Lutfi, A. M., Erlangga, H., Nurjaya, N., Priadana, S., \& Dwiwarman, D. A. (2021). Pengaruh Capital Adequacy Ratio Dan 
Bopo Ratio Terhadap Return On Asset Pada Pt. Bank Muamalat Indonesia, Tbk Periode 2010-2019. Jurnal Ekonomi Efektif, 3(3).

M. A, Sumanto " Teori dan Aplikasi Metode Penelitian" Cetakan Pertama, CAPS (Center of Academic Publishing Service), Yogyakarta, 2014

Najibullah, et al. (2021). Pengaruh non Performing Financing dan Financing to Deposit Ratio terhadap Pembiayaan pada Bank DKI Syariah. Jurnal Neraca Peradaban. Volume 1. Issue1. Pages 485

Nur Zaman, Januar. "Pengaruh Kompetensi dan Independensi Auditor terhadap Kualitas Audit (Studi Empiris pada KAP di Jakarta Selatan)". Skripsi, Universitas Pamulang, 2013.

Muslimat, A., Muhsin, H., Wahid, H. A., Yulistiana, I., Sunarsi, D., Dewi, K., ... \& Ilham, D. (2021). Develop Technology Based Multimedia For Indonesian Teachers. Journal of Contemporary Issues in Business and Government, 27(1), 1871-1882.

Purwanti, Y. (2021). The Influence Of Digital Marketing \& Innovasion On The School Performance. Turkish Journal of Computer and Mathematics Education (TURCOMAT), 12(7), 118-127.

Muslimat, A. (2021). Masa Depan Kampus Merdeka \& Merdeka Belajar: Sebuah Bunga Rampai Dosen. Bintang Visitama Publisher.

Nurjaya, N., Affandi, A., Ilham, D., Jasmani, J., \& Sunarsi, D. (2021). Pengaruh Kompetensi Sumber Daya Manusia Dan Kemampuan Pemanfaatan Teknologi Terhadap Kinerja Aparatur Desa Pada Kantor Kepala Desa Di Kabupaten Gunungkidul, Yogyakarta. JENIUS (Jurnal Ilmiah Manajemen Sumber Daya Manusia), 4(3), 332-346.

Nurjaya, et al (2021). Pengaruh Liquiditas dan Profitabilitas terhadap Return
Saham: Studi Empiris Pada Perusahaan Real Estate Dan Property Yang Terdaftar Di Bursa Efek Indonesia Tahun 2017-2019. Jurnal Tadbir Peradaban Volume 1. Issue.1. Pages 6068.

Pujiati, H., Sunarsi, D., Affandi, A., \& Anggraeni, N. (2021). Effect of ISO 9001: 2015 Quality Management Implementation in Education on School Performance. Journal of Contemporary Issues in Business and Government, 27(1), 1848-1855.

Sagara, Yusar dan Fitri Yani Jalil "Auditing." Cetakan ke-1, Uin Jakarta Press, Jakarta 2013.

Salam, A., Hikmat, I., Haquei, F., \& Badariah, E. (2021). The Influence of Share Ownership, Funding Decisions, Csr and Financial Performance of Food Industry. Annals of the Romanian Society for Cell Biology, 12698-12710.

Sugiyono "Metode Penelitian Bisnis" Cetakan kesembilan, ALFABETA. CV. Bandung, 2006.

Sunjoyo, Rony Setiawan, Verani Carolina, dkk "Aplikasi SPSS untuk Smart Riset

Sunyoto, Danang, "Auditing (Pemeriksaan Akuntansi)."Cetakan satu, CAPS, Yogyakarta, 2014.

Suraida, Ida. "Pengaruh Etika, Kompetensi, Pengalaman Audit dan Risiko Audit terhadap Skeptisisme Profesional Auditor dan Ketepatan Pemberian Opini Akuntan Publik". Sosiohumaniora, Vol. 7, No. 3, 186-202, 2005.

Trihendradi, C "Ilmu Statistik untuk Ilmu Sosial dan Kesehatan + Konsep Penerapannya menggunakan SPSS." Edisi 1, ANDI, Yogyakarta, 2013.

William F. Messier, Jr. dkk " Auditing \& Assurance Service a Systematic Approach." Edisi 4, Salemba Empat, Jakarta, 2006. 